NASA/TM-2003-212599

ARL-TR-2921
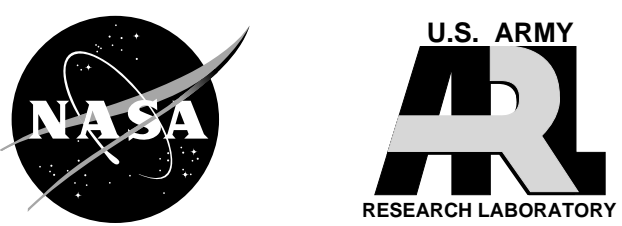

GT-2003-38524

\title{
Experimental Investigation of Centrifugal Compressor Stabilization Techniques
}

Gary J. Skoch

U.S. Army Research Laboratory, Glenn Research Center, Cleveland, Ohio 
Since its founding, NASA has been dedicated to the advancement of aeronautics and space science. The NASA Scientific and Technical Information (STI) Program Office plays a key part in helping NASA maintain this important role.

The NASA STI Program Office is operated by Langley Research Center, the Lead Center for NASA's scientific and technical information. The NASA STI Program Office provides access to the NASA STI Database, the largest collection of aeronautical and space science STI in the world. The Program Office is also NASA's institutional mechanism for disseminating the results of its research and development activities. These results are published by NASA in the NASA STI Report Series, which includes the following report types:

- TECHNICAL PUBLICATION. Reports of completed research or a major significant phase of research that present the results of NASA programs and include extensive data or theoretical analysis. Includes compilations of significant scientific and technical data and information deemed to be of continuing reference value. NASA's counterpart of peerreviewed formal professional papers but has less stringent limitations on manuscript length and extent of graphic presentations.

- TECHNICAL MEMORANDUM. Scientific and technical findings that are preliminary or of specialized interest, e.g., quick release reports, working papers, and bibliographies that contain minimal annotation. Does not contain extensive analysis.

- CONTRACTOR REPORT. Scientific and technical findings by NASA-sponsored contractors and grantees.
- CONFERENCE PUBLICATION. Collected papers from scientific and technical conferences, symposia, seminars, or other meetings sponsored or cosponsored by NASA.

- SPECIAL PUBLICATION. Scientific, technical, or historical information from NASA programs, projects, and missions, often concerned with subjects having substantial public interest.

- TECHNICAL TRANSLATION. Englishlanguage translations of foreign scientific and technical material pertinent to NASA's mission.

Specialized services that complement the STI Program Office's diverse offerings include creating custom thesauri, building customized databases, organizing and publishing research results ... even providing videos.

For more information about the NASA STI Program Office, see the following:

- Access the NASA STI Program Home Page at http://www.sti.nasa.gov

- E-mail your question via the Internet to help@sti.nasa.gov

- Fax your question to the NASA Access Help Desk at 301-621-0134

- Telephone the NASA Access Help Desk at 301-621-0390

- Write to:

NASA Access Help Desk

NASA Center for AeroSpace Information 7121 Standard Drive

Hanover, MD 21076 
NASA/TM-2003-212599

ARL-TR-2921
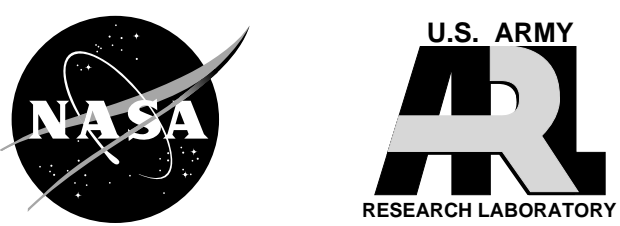

GT-2003-38524

\title{
Experimental Investigation of Centrifugal Compressor Stabilization Techniques
}

\author{
Gary J. Skoch \\ U.S. Army Research Laboratory, Glenn Research Center, Cleveland, Ohio
}

Prepared for the

Turbo Expo 2003

cosponsored by the American Society of Mechanical Engineers

and the International Gas Turbine Institute

Atlanta, Georgia, June 16-19, 2003

National Aeronautics and

Space Administration

Glenn Research Center 


\section{Acknowledgments}

The author would like to thank Thomas Jett, Winston Johnson, and Antonio Zaldana for test cell operation; Scott Panko, Edith Parrott, and Harry Fuller for electronics support; and Mark Stevens for hardware design. Special thanks also go to Dr. Anthony Strazisar for both programmatic and technical support of the project.

This work was sponsored by the Low Emissions Alternative

Power Project of the Vehicle Systems Program at the NASA Glenn Research Center.

Available from

NASA Center for Aerospace Information 7121 Standard Drive

Hanover, MD 21076
National Technical Information Service 5285 Port Royal Road Springfield, VA 22100 


\title{
EXPERIMENTAL INVESTIGATION OF CENTRIFUGAL COMPRESSOR STABILIZATION TECHNIQUES
}

\author{
Gary J. Skoch \\ U.S. Army Research Laboratory \\ National Aeronautics and Space Administration \\ Glenn Research Center \\ Cleveland, Ohio 44135
}

\section{ABSTRACT}

Results from a series of experiments to investigate techniques for extending the stable flow range of a centrifugal compressor are reported. The research was conducted in a highspeed centrifugal compressor at the NASA Glenn Research Center.

The stabilizing effect of steadily flowing air-streams injected into the vaneless region of a vane-island diffuser through the shroud surface is described. Parametric variations of injection angle, injection flow rate, number of injectors, injector spacing, and injection vs. bleed were investigated for a range of impeller speeds and tip clearances. Both the compressor discharge and an external source were used for the injection air supply.

The stabilizing effect of flow obstructions created by tubes that were inserted into the diffuser vaneless space through the shroud was also investigated. Tube immersion into the vaneless space was varied in the flow obstruction experiments.

Results from testing done at impeller design speed and tip clearance are presented. Surge margin improved by 1.7 points using injection air that was supplied from within the compressor. Externally supplied injection air was used to return the compressor to stable operation after being throttled into surge. The tubes, which were capped to prevent mass flux, provided 6.5 points of additional surge margin over the baseline surge margin of 11.7 points.

\section{INTRODUCTION}

The effort to determine the causes, precursors and control mechanisms for stall and surge in both axial and centrifugal compressors has had many contributors over the years. Rodgers [1] tested numerous channel diffusers with back-swept impellers and found that diffuser initiated surge occurred at a nearly constant impeller to throat diffusion ratio of 1.8 for
Mach numbers below unity. Rodgers concluded that a rapid accumulation of blockage near the diffuser throat limits the achievable diffusion ratio. The work was based in part on earlier work by Rundstadler and Dean [2] who demonstrated the importance of diffuser throat boundary layer blockage to the pressure recovery of the channel diffuser. Both works show the sensitivity of compressor performance to flow conditions in the vaneless and semi-vaneless regions of a channel diffuser.

A number of investigators have also demonstrated various strategies to extend the stable flow range of centrifugal compressors. Jansen et al. [3] reported the stabilizing effect of a slotted hub-wall treatment, beginning at the impeller exit and extending downstream of the diffuser throat, applied to a variable geometry vaned diffuser. Raw [4] demonstrated surge margin improvement in a conical pipe diffuser by using "porous drillings" to bleed flow from the region of the diffuser throat. Nelson et al. [5] reported a successful effort to stabilize the axial-centrifugal compressor of a turbo-shaft engine using both steady-flow and pulsed injection of air into the diffuser channels through slots in the suction side of the vanes.

Stein et al. [6] conducted 3-D time accurate simulations of a high-speed centrifugal impeller at surge conditions. Air injection at the impeller inlet was added to the model and several parametric variations of injection angle were analyzed. The computations showed that a flow reversal occurred on the leading edge of the impeller blades at reduced mass flow conditions. Air injection eliminated a local separation that was causing flow reversal and improved impeller stability.

Oakes et al. [7] worked to characterize the instability in a high-speed centrifugal compressor as it approached and entered surge. Arrays of high response pressure transducers were located upstream of the impeller inlet and in the endwall of the vaned diffuser. Two rotating stall modes were identified, a nine-cell mode that was a precursor to the initial surge cycle 
and a single cell mode that coincided with surge initiation. Both modes were found to be located near the diffuser.

Spakovszky [8] extended the Moore-Greitzer stability model for axial compression systems to centrifugal compressors by adding a radial duct to model the vaneless region between the impeller and vaned diffuser. The improved stability model also shows the importance of the vaneless space to compressor stability but from the viewpoint of system dynamics. The radial extent of the vaneless region and the amount of swirl in flow entering from the impeller discharge are important parameters that influence system stability. The improved model predicted a vaneless space disturbance rotating in a direction opposite the impeller. Working in the same compressor used for the experiments reported herein, Spakovszky verified the predicted disturbance and went on to demonstrate range improvement using small amounts of externally supplied air injected tangentially into the diffuser vaneless space in the direction of impeller rotation.

The motivation for the present work was to improve the stable flow range of centrifugal compressors by modifying flows in the vaneless and semi-vaneless regions of the diffuser. One strategy was to design a system of injectors that could provide variations in position, direction and flow rate to affect as many regions of the diffuser as possible. To implement that strategy, nozzles were installed through both the hub and shroud surfaces of the diffuser and air injection was tested at several impeller tip clearances and operating speeds. Another strategy implemented only on the shroud surface employed tubes that were inserted into the diffuser vaneless space to bleed low momentum flow discharging from the impeller tip.

This paper focuses on the techniques applied to the shroudside of the diffuser. Results are presented from tests that were done at design speed with a constant tip clearance of 2.4 percent of impeller blade exit height.

\section{TEST COMPRESSOR}

The test compressor is an Allison Engine Company design that was scaled up to a flow size of $10 \mathrm{lb}_{\mathrm{m}} / \mathrm{s}(4.54 \mathrm{~kg} / \mathrm{s})$ from the original size of $3.655 \mathrm{lb} / \mathrm{s}(1.66 \mathrm{~kg} / \mathrm{s})$. McKain and Holbrook [9] give complete aerodynamic and mechanical design descriptions, including impeller and diffuser geometries.

The stage (impeller with vane-island diffuser) was designed to produce a pressure ratio of $4: 1$ at the design mass flow. The standard day corrected speed for the design flow condition is $21,789 \mathrm{rev} / \mathrm{min}$ with an exit tip speed of $1615 \mathrm{ft} / \mathrm{s}$ $(492 \mathrm{~m} / \mathrm{s})$. The inlet relative Mach numbers on the suction surface range from 0.9 at the tip to 0.45 at the hub. The impeller contains 15 main blades and 15 splitter blades and has 50 degrees of backsweep from radial at the discharge. The splitter-blade leading edge, located at 20 percent of main blade chord, is offset slightly toward the main-blade suction surface in order to produce an even flow split. Both the main blades and splitter blades are formed from quasi-normal straight-line elements between the hub and tip. The inlet tip diameter is 8.264 in $(210 \mathrm{~mm})$ and the inlet blade height is 2.501 in
$(64 \mathrm{~mm})$. The exit diameter is 16.986 in $(431 \mathrm{~mm})$ and the exit blade height is 0.671 in $(17 \mathrm{~mm})$. All dimensions are for hot conditions at 100 percent of design speed.

The vane-island diffuser contains twenty-four passages. The vane leading edge is at a radius ratio of 1.08 and the midpitch of the passage throat is at a radius ratio of 1.10 . The diffuser exit is at a radius ratio of 1.68 .

\section{SURGE CONTROL APPARATUS}

Cross sections of the centrifugal compressor test-rig, a shroud injector and the air supply system are shown in Figure 1. Also shown is one of eight recirculation air pickups that were used for a configuration where recirculating air was supplied to the injectors.

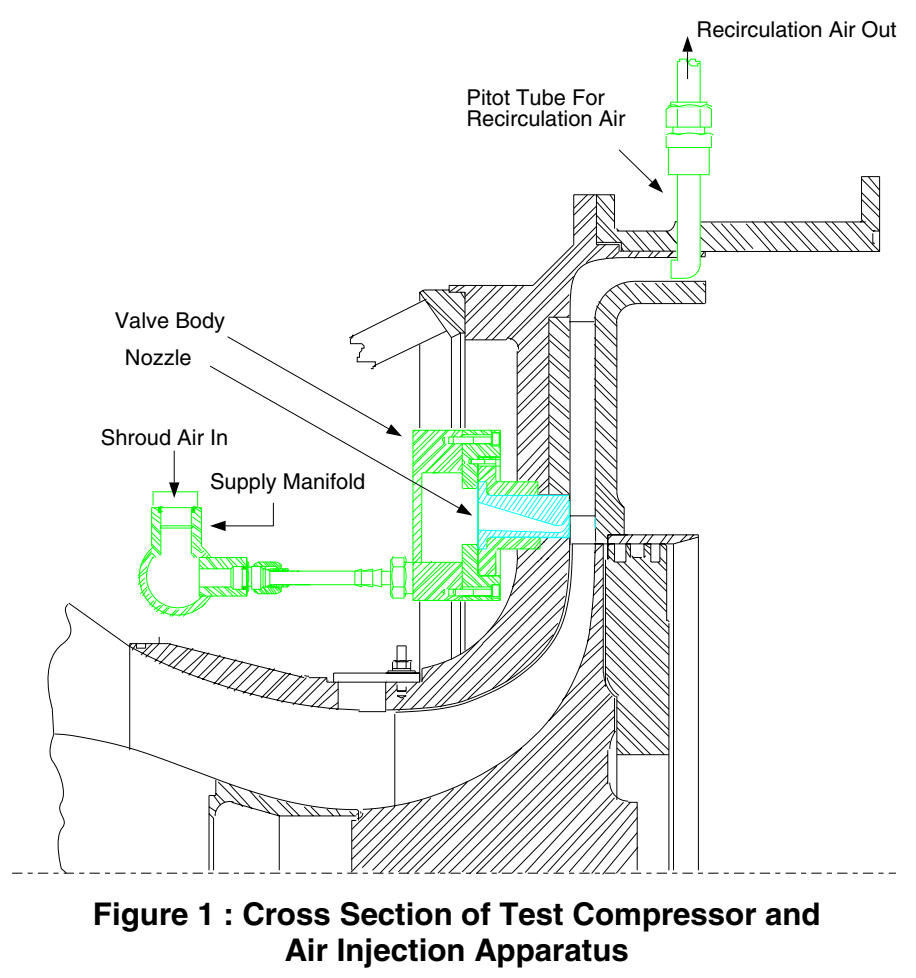

\section{Shroud Side Injectors}

Eight injector nozzles were installed on the shroud side of the diffuser as shown in Figure 2. The injector nozzles were contained in valve bodies that had been designed for pulsedinjection experiments where a voice-coil type actuator drove an internal valve, hence the large size. The injection nozzles were interchangeable to permit testing of the wall-jet directions shown in Figure 3.

Only steady flow injection was used in these experiments. Injection air was supplied to all eight valve bodies by an external manifold located around the circumference of the inlet. The manifold was supplied by an external air source or by recirculating flow collected through eight Pitot tube pickups located at the diffuser discharge (Figure 1). 


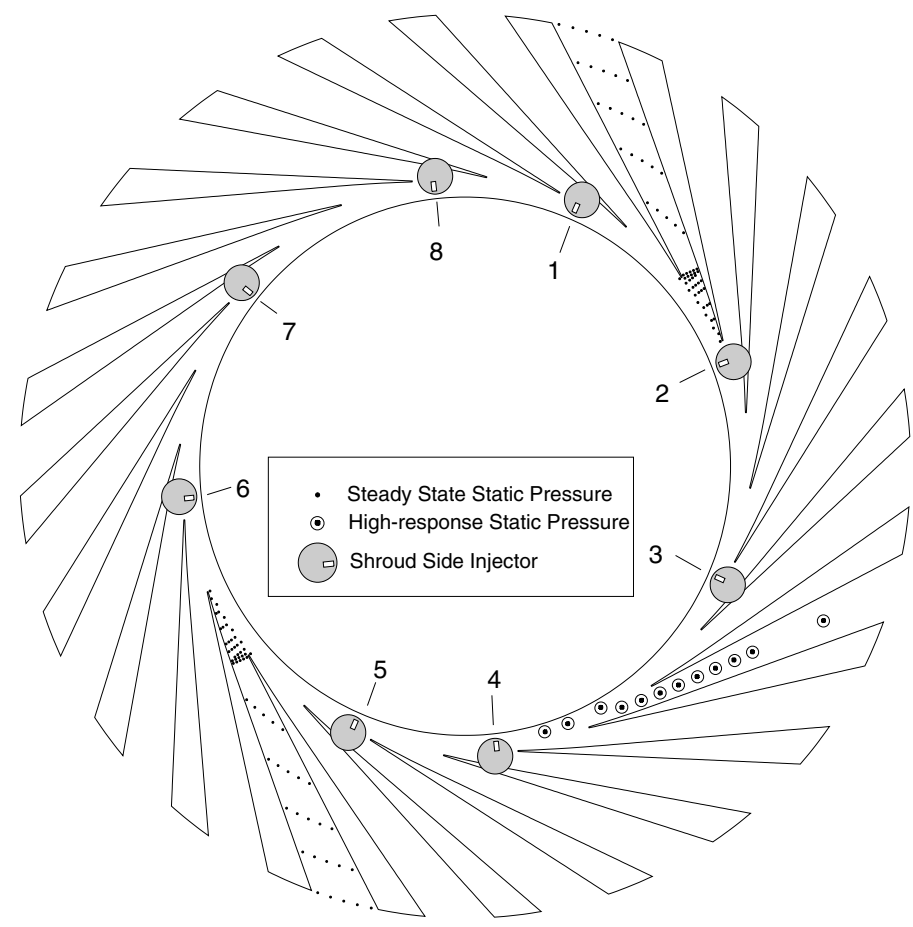

Figure 2: Diffuser Shroud Instrumentation and Injector Locations

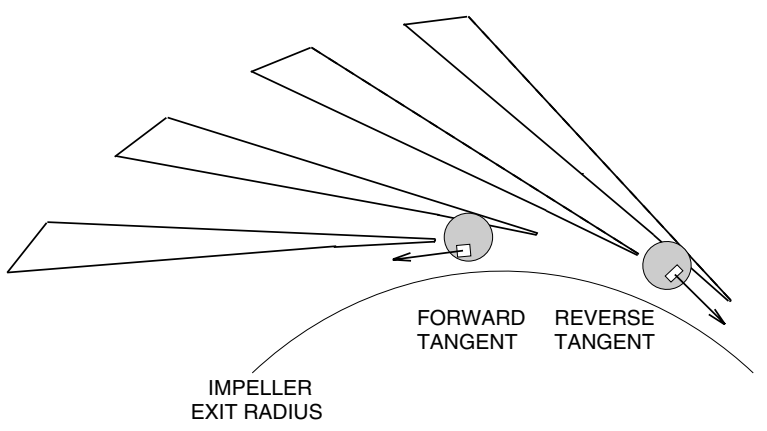

Figure 3: Shroud Side Injector Orientations

\section{Control Tubes}

Tubes were inserted through the shroud-side injector openings into the diffuser vaneless space as shown in Figure 4. The tubes were fabricated from 0.375 inch $(10 \mathrm{~mm})$ diameter steel tubing that was bent to align the end residing inside the flow path with the local absolute velocity vector. The interior end was also partially recessed into the carrier plug to limit its immersion to fifty percent of diffuser span when the plug was fully seated without shims. Shims were placed under the exterior flange of the plug to achieve lesser immersions. Eight tubes could be installed using the same openings employed by the shroud side injectors (Figure 2). The tubes provided a bleed path for the impeller discharge when the exterior ends were left open. However, the results reported here are from tests done with the external ends capped to prevent any mass flux through the tube.

\section{TEST PROCEDURE, INSTRUMENTATION}

Compressor stability experiments were completed over a speed range of 60 to 100 percent of design speed and at tip clearances of 2.4, 3.6 and 4.8 percent of exit blade height. Results from tests done at 100 percent of design speed with a tip clearance equal to 2.4 percent of exit blade height are reported here. At each condition, the compressor was throttled to a starting point on the operating characteristic that was near surge for the baseline compressor and then ramped into surge by closing the throttle slowly at a constant rate.

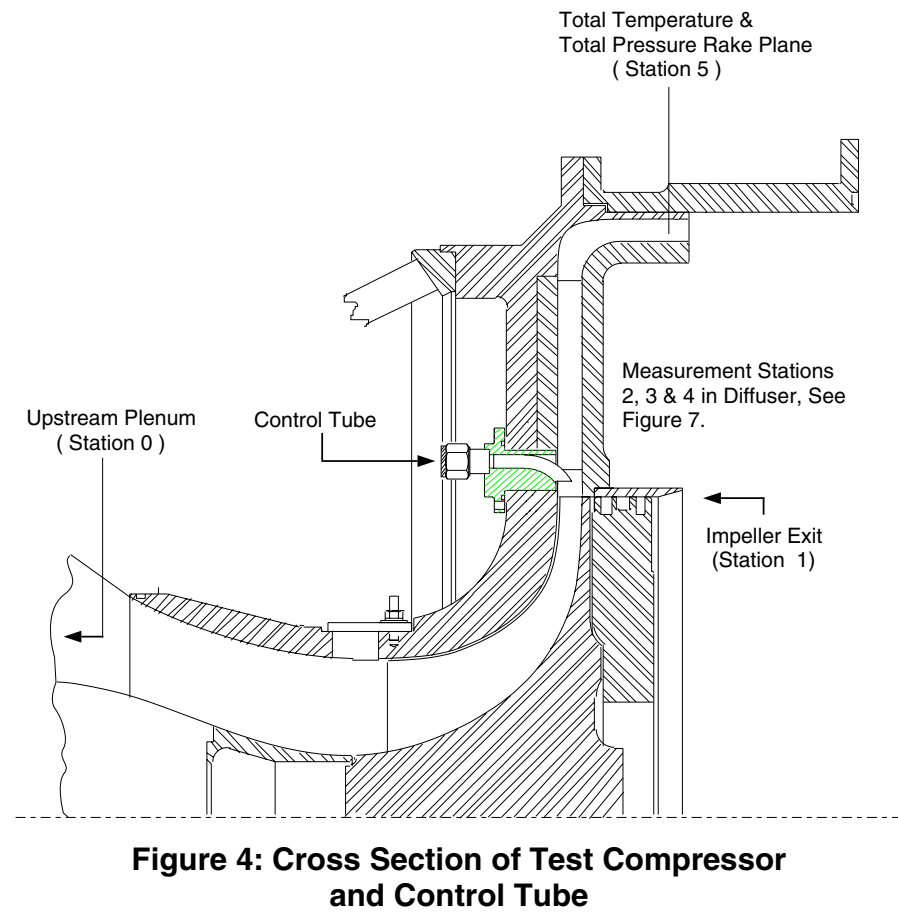

The flow rate where the compressor surged was determined by noting the flow rate where an audible change occurred in the sound emanating from the compressor. As a check on the audible indicator, the pressure delta across the main flow orifice was digitized during the ramps. A second surge flow rate was later determined from the digitized orifice data to verify the initial number. The computed surge flow rate was generally lower than the audible surge rate. The audible surge flow rates reported herein are within -0.05 and $+0.15 \mathrm{lb}_{\mathrm{m}} / \mathrm{s}(-23$ and $+68 \mathrm{~g} / \mathrm{s})$ of the computed value.

The surge flow-rate was sensitive to changes in impeller tip clearance. Air injection changed the local metal temperature enough to change the clearance between the impeller trailing edge and the shroud. After arriving at a starting point on the characteristic that was near surge, the flow path dimensions were allowed to adjust to the temperature conditions created by air injection. The tip clearance was then adjusted to its initial value using a unique feature of the test rig that permits controlled axial movement of the impeller during operation. Tip clearance was measured during operation using a highvoltage touch-probe system.

High-response diffuser pressure data was collected using 50 psid $\left(34 \mathrm{~N} / \mathrm{cm}^{2}\right)$ Kulite pressure transducers. Data were recorded at a $2.5 \mathrm{KHz}$ sampling rate with the raw signal filtered 
to a bandwidth of $1 \mathrm{KHz}$. The high-response transducers were located only on the shroud side of the diffuser as shown in Figure 2. One passage was heavily instrumented with transducers located along a mid-pitch line extending from the vaneless space to a point near the passage exit.

Steady-state static pressure arrays were located in two passages on each of the shroud and hub surfaces. The shroud side static pressure arrays are shown in Figure 2. Similar arrays were located on the hub. Stage total temperature and total pressure rise were determined from measurements collected in the upstream plenum and from rakes located in the discharge channel downstream of the diffuser. The downstream rake plane is marked in Figure 4. Six, four-element total pressure rakes and eight, three-element total temperature rakes were located in the downstream plane. Five of the total temperature rakes and three of the total pressure rakes were replaced by Pitot tubes when recirculated air was used to supply injectors.

Steady-state data were collected using the test cell data system (Escort System) that records all steady-state pressure, temperature and speed data needed to determine compressor performance. Steady-state measurement uncertainties are less than $0.1 \mathrm{psi}\left(0.07 \mathrm{~N} / \mathrm{cm}^{2}\right)$ pressure, $1^{\circ} \mathrm{R}\left(0.6^{\circ} \mathrm{C}\right)$ temperature, and $0.05 \mathrm{lb} / \mathrm{s}(0.02 \mathrm{~kg} / \mathrm{s})$ mass flow. The Escort System was also used to collect performance data while ramping toward surge since the throttle was being closed slowly. Data readings were taken at roughly $0.1 \quad \mathrm{lb}_{\mathrm{m}} / \mathrm{s}(45 \mathrm{~g} / \mathrm{s})$ flow increments between the ramp starting point and the surge point.

\section{EXPERIMENTAL RESULTS}

Pressure rise characteristics, shown in Figure 5, illustrate the range improvement provided by each shroud-side technique. Some of the results are shown as complete speed lines, others as partial speed lines beginning near the surge flow rate of the baseline characteristic.

All of the characteristics in Figure 5 were obtained with injector nozzles installed on the hub surface. The hub nozzle air supply was closed for these experiments but a manifold between each nozzle and air supply lines permitted communication between nozzles. This communication improved the stable flow-range of the compressor, as did the porous drillings described by Raw [4]. In the present work, the surge flow rate for the baseline compressor was approximately $0.1 \mathrm{lb}_{\mathrm{m}} / \mathrm{s}$ (45 g/s) lower than it was for the same compressor with a solid diffuser hub surface.

The inlet corrected mass flow on each characteristic shown in Figure 5 was adjusted to account for the air that was injected into the diffuser since it was injected downstream of the main flow orifice. Mass flow was adjusted by adding the absolute injection flow rate to the absolute flow rate at the compressor inlet and then correcting the sum to inlet conditions. The adjustment was made for both recirculated and external air supplies in order to determine the flow rate through the diffuser.

The final data point shown on each characteristic is at the flow rate determined from the audible surge indicator, adjusted for injection. The location of the data point on the ordinate was determined from a second order curve fit of three to six data points preceding surge.

Surge margin is typically used as an indicator of range improvement when comparing compressor designs, where surge margin is defined as:

$$
\mathrm{SM}=\left(1-\frac{\pi \text { ref }_{\text {surge }}}{\boldsymbol{\pi}_{\text {surge }}}\right) \times \frac{\dot{\mathrm{m}}_{\text {ref }}}{\dot{\mathrm{m}}_{\mathrm{s}}} \times 100 \% \text { and } \boldsymbol{\pi}=\frac{\mathrm{P}_{5}}{\mathrm{P}_{0}}
$$

Each technique produced a unique pressure rise characteristic. A similar reference point on each characteristic is needed in order to compute surge margins that can be compared between the techniques. The reference points shown on each characteristic curve in Figure 5 lie along a line of constant compressor-exit corrected flow computed at the design point of the baseline compressor. Reference points were estimated using second order curve fits of the measured points. Reference points in Figure 5 that do not coincide with a measured point are indicated by a hexagon that surrounds the symbol.

\section{Forward-Tangent Injection}

The hardware configuration of forward-tangent injection is shown in Figures 2 and 3. The injected air stream was in the direction of impeller rotation and coincident with the tangential component of the impeller discharge flow. The center of the injector opening was at a radius ratio of 1.04. The nozzles were sized to choke when 5 percent of compressor design mass flow was injected through eight nozzles $(0.62 \%$ per nozzle) using air supplied at $80^{\circ} \mathrm{F}\left(27^{\circ} \mathrm{C}\right)$.

Spakovszky [8] first demonstrated the effectiveness of this configuration using externally supplied injection air. It was investigated again to determine whether the range improvement could be duplicated using an internal air supply. In the current work, injection air was taken from the diffuser discharge using the Pitot style pickups shown in Figure 1. The open circles in Figure 5 show results from forward-tangent injection using eight injectors.

Forward-tangent injection rates between 0.3 and 2.1 percent of design flow were tested. There was little variation in stage pressure ratio or flow range between the curves that were obtained. An injected flow rate of 0.9 percent produced the largest increase in stable flow range. The total pressure ratio at surge decreased by 1 percent compared to the baseline surge pressure ratio.

Design point surge margin on the baseline curve is 11.7 percent, computed using the design flow point of $10 \mathrm{lb}_{\mathrm{m}} / \mathrm{s}$ $(4.54 \mathrm{~kg} / \mathrm{s})$ as a reference. Surge margin improved to 13.4 percent with $0.9 \%$-forward-tangent injection. The improvement in surge margin is 14 percent $\left(\Delta \mathrm{SM} / \mathrm{SM}_{\text {Baseline }}\right)$, which is much less than the 27 percent gain reported by Spakovszky [8]. However, baseline surge margin for the current configuration was higher due to the communication between hub injectors that was noted earlier. 


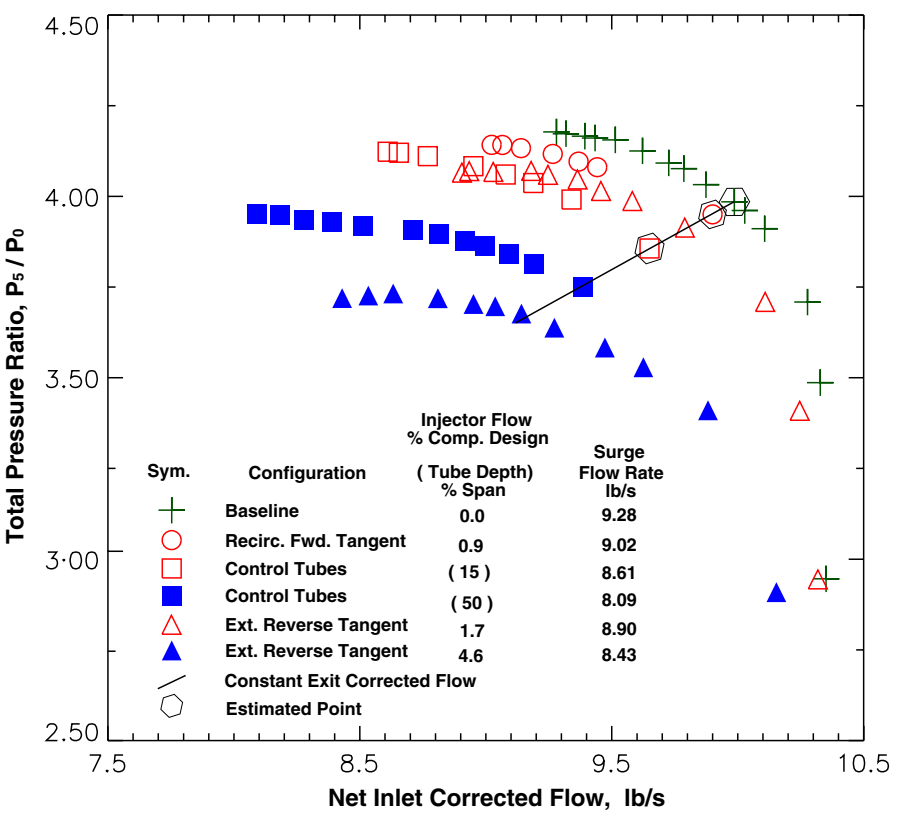

Figure 5: Total Pressure Ratio Characteristics at Design Speed and 2.4 Percent Tip Clearance.

\section{Reverse-Tangent Injection}

The reverse-tangent injector configuration is shown in Figure 3. Eight injector nozzles were installed at the locations shown in Figure 2. The injected stream was coincident with the tangential component of the impeller discharge flow at a radius ratio of 1.04 , but the direction of the jet was opposed to impeller rotation. The total pressure at the injector opening had to be greater than the stagnation pressure of the impeller discharge to inject flow against impeller rotation. As such, an external air supply was used.

Injector flow rates ranging between 0.5 and 4.6 percent of compressor design flow were tested. The solid triangles in Figure 5 are data from the highest injector flow rate. The open triangles are results from the middle of the injection flow-range at 1.7 percent of compressor design flow. Comparing the two characteristics shows that the stable flow range increased as injector flow rate increased, but the loss in total pressure ratio increased as well.

Reverse-tangent injection at 1.7 percent of compressor design flow provided a surge margin of 12.7 percent. When the injected flow rate was increased to 4.6 percent of design flow, the stable flow range increased but the pressure ratio at surge dropped substantially, losing 11 percent compared to the baseline pressure ratio. Surge margin decreased to 9.7 percent as a result.

Comparing the two reverse-tangent characteristics reveals part of the reason for the loss in pressure ratio. When the mass flow data along the $1.7 \%$-characteristic was adjusted to account for the effect of external air injection, the first operating point along the choked flow segment of the characteristic aligned with the first point on the baseline characteristic. A loss in pressure ratio is evident at subsequent points on the $1.7 \%$-characteristic that diminishes somewhat as surge is approached. Shifting the $4.6 \%$-characteristic did not produce the same choked flow alignment and the loss of pressure ratio is more substantial at low flow rates. Reverse-tangent injection reduces the tangential velocity component of flow entering the diffuser, beginning on the shroud surface and extending into some portion of the diffuser passage. At high injector flow rates the reverse-tangent process is inefficient and the dynamic head that could be recovered is lost instead. The resulting compressor characteristic appears to move down a constant throttle line as if compressor speed was being reduced.

\section{Control Tubes}

The final data set presented in Figure 5 (squares) shows results from the control tube configuration where the outer ends were capped to prevent mass flux through the tubes. Only seven tubes were used in order to avoid a vibration mode in the impeller that could be excited by an eight per rev disturbance at design speed.

Laser anemometer surveys of this impeller (Skoch et al. [10]) showed that a region of fluid with low through flow velocity accumulates near the impeller tip along the suction surface of the blade. The low through-flow velocity fluid contributes to a jet-wake profile at the impeller exit. The original intent behind the control tube design was to bleed some of the low momentum fluid discharging from the impeller and re-inject that fluid at the impeller inlet, which was shown to benefit impeller stability in computations by Stein et al. [6]. However, a stabilizing influence was found to result simply from the presence of control tubes in the diffuser. It was not enhanced by bleed and, since the diffuser is the least stable element in this compressor, re-injection into the impeller did not impact the stable flow range.

Immersion into the vaneless space was varied during control tube experiments since bleed flow was not used. Figure 5 shows results obtained from two immersions. The open squares were obtained when the leading edge of the tube was immersed in the vaneless space to a depth of 15 percent of the local span. The solid squares represent data from a 50 percent immersion.

The 15\%-control-tube configuration provided a surge margin of 16.1 percent while losing only 1.4 percent in pressure ratio at surge. The $50 \%$-control-tubes provided a surge margin of 18.2 percent with a 5.5 percent decrease in pressure ratio at surge. The control tube configuration follows the pattern of reverse tangent injection where pressure ratio is traded for flow range. However, the level of pressure loss for a given improvement in range is much less with the control tubes.

\section{Surge Mechanism}

A surging flow condition in a centrifugal compressor is most likely the result of many factors that contribute individually or in combination to a final event that triggers surge. In this compressor, the event that precipitates surge occurs in the diffuser.

Figure 6 is an X-T diagram of high-response pressure measurements collected in the diffuser through one surge cycle in the baseline configuration. The operating condition was design speed with 2.4 percent impeller exit tip clearance. The pressure transducers used to construct the contours were 
located along the center of the diffuser passage as shown in Figures 2 and 6. Measurements from two vaneless space transducers in line with the passage row are included. A pressure trace from the first vaneless space transducer is also shown in Figure 6.

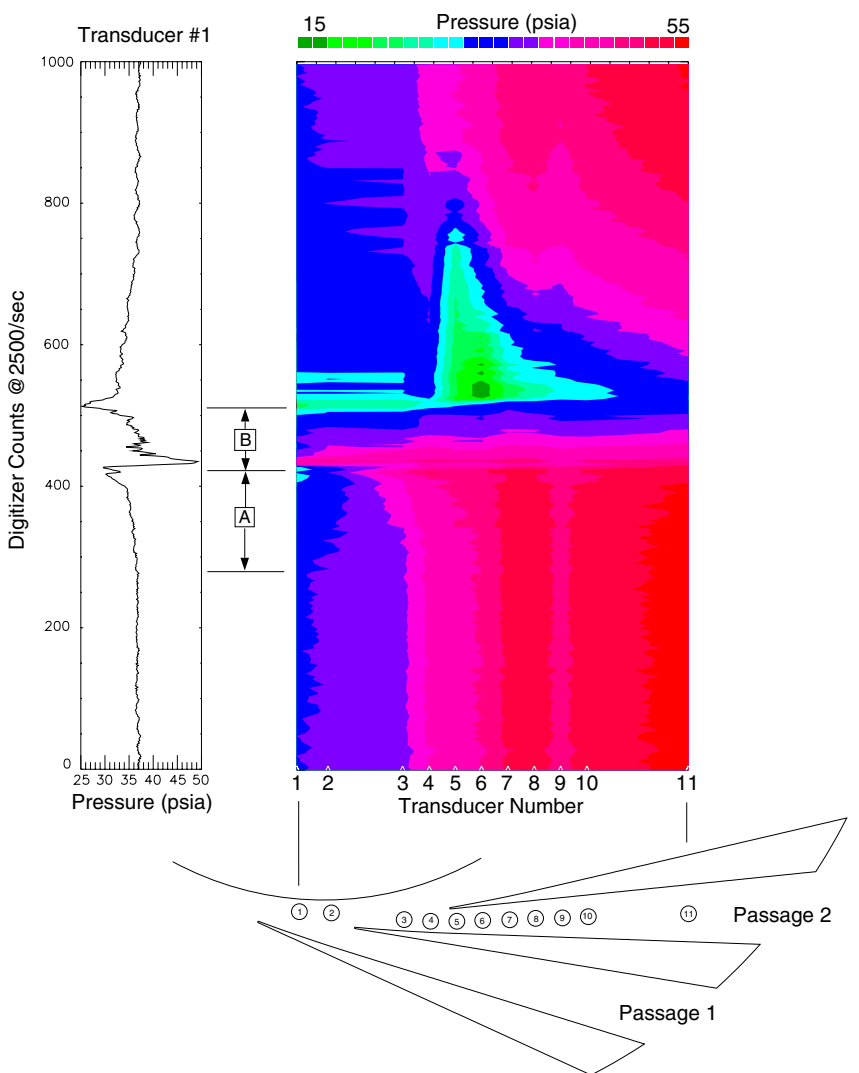

Figure 6: X-T Diagram of Diffuser Passage Pressures through One Surge Cycle

Wernet et al. [11] used Particle Image Velocimetry to visualize flow fields in this diffuser during surge and then connected the observations to a simultaneous measurement of pressure variation in the diffuser throat. A reversal in flow direction through the diffuser was observed during the time interval indicated by Region B in Figure 6. A sudden spike in pressure at the diffuser throat marked the beginning of the reverse flow period, which continued until a subsequent minimum in pressure occurred. The pressure profile from Transducer 1 shows the same characteristic spike in pressure followed by an immediate decrease to the minimum for the surge cycle.

Region A in Figure 6 highlights a time interval just before surge. The pressures at Transducers 1 and 2 are gradually decreasing, while the pressure at Transducer 3 is gradually increasing. A rapid increase in vaneless space pressure occurs at surge, suggesting that a sudden collapse in diffusion is taking place upstream of the diffuser throat. Static pressure in the diffuser passage then drives a compression wave upstream into the vaneless space.

Blockage created by flow defects forming on either endwall of the vaneless space or near the leading edge of the lower vane in Passage 1 could explain the observed condition.
A reduction in flow area created by the defect would lower the static pressure in the leading edge region of the vaneless space requiring higher diffusion levels to support the existing static pressure gradient. Diffusion across the vaneless space eventually reaches a limit, existing downstream static pressure levels can no longer be supported, and diffuser flow suddenly reverses direction.

\section{Surge Control Mechanisms}

A significant interaction with the tangential component of velocity in flow entering the diffuser is a common element of the techniques that were tested here. Reverse-tangent injection and control tubes act directly against that component. A reduction in vaneless space tangential velocity and some mixing of the jet-wake profile on the shroud surface are likely to occur. At the same time, both injection and control tubes reduce the local through-flow area of the diffuser vaneless space and accelerate the through-flow component at lower spans. The combination results in lower average flow angles entering the diffuser.

When the flow angle at the diffuser entrance is reduced both diffusion ahead of the throat and incidence angles at the vane leading edge are also reduced. Rodgers [1] cites the level of diffusion taking place between the impeller trailing edge and the diffuser throat as a stability factor in a centrifugal compressor with a channel diffuser. Blockage growth increases with diffusion to the point that diffusion is reduced by accumulated blockage, leading to a positively sloped static pressure rise characteristic.

Spakovszky [8] developed a system model for centrifugal compressors to predict destabilizing flow resonance caused by unsteady interactions between the impeller and diffuser. Flow angle in the diffuser vaneless space was shown to influence the harmonic number of certain disturbances. Reducing flow angle in the vaneless space may have prevented the formation of one such backward rotating disturbance.

Diffuser performance, leading edge incidence and backward rotating instability modes are discussed in more detail next.

\section{Diffuser Performance}

Diffusion occurring ahead of the throat was reduced for a given compressor flow rate by each technique. Diffuser static pressure rise coefficients are shown for the vaneless, semivaneless and vaned-passage regions of the diffuser in Figures 7 through 9. Static pressures measured on the hub and shroud at each element boundary were averaged before computing the static pressure rise across each element.

Vaneless Space. Figure 7 shows the static pressure rise coefficient across the diffuser vaneless space. The baseline configuration shows a slight decrease in pressure rise as the compressor is throttled. When the baseline configuration was tested with a solid hub surface the curve was increasing slightly as compressor flow was reduced. The opposite slope in this case is attributed to the communication between hub injectors that was noted earlier. 
Data collected for the extended range configurations show a lower static pressure rise than the baseline at high throughflow rates. The decline in pressure rise at high through-flow is due to reduced flow area caused by injected air and to a loss of total pressure caused by interaction with the free-stream. Both reverse-tangent injection and control tubes act against the tangential component of velocity in the flow field so an increase in pressure loss is not unexpected.

At high compressor through-flow rates, the tangential velocity component in air leaving the impeller is low and the losses associated with a head-on interaction between the injected jets or control tubes and the tangential component are small. As compressor through-flow is reduced the tangential component grows and the interaction produces increasing total pressure loss. Hence, the further reduction in static pressurerise seen as compressor though-flow is reduced.

There is an inflection point on all but one of the characteristics where the slope turns negative and static pressure rise begins to increase. The maximum pressure loss caused by the interaction has been achieved at the inflection point and diffusion resumes as the compressor is throttled further.

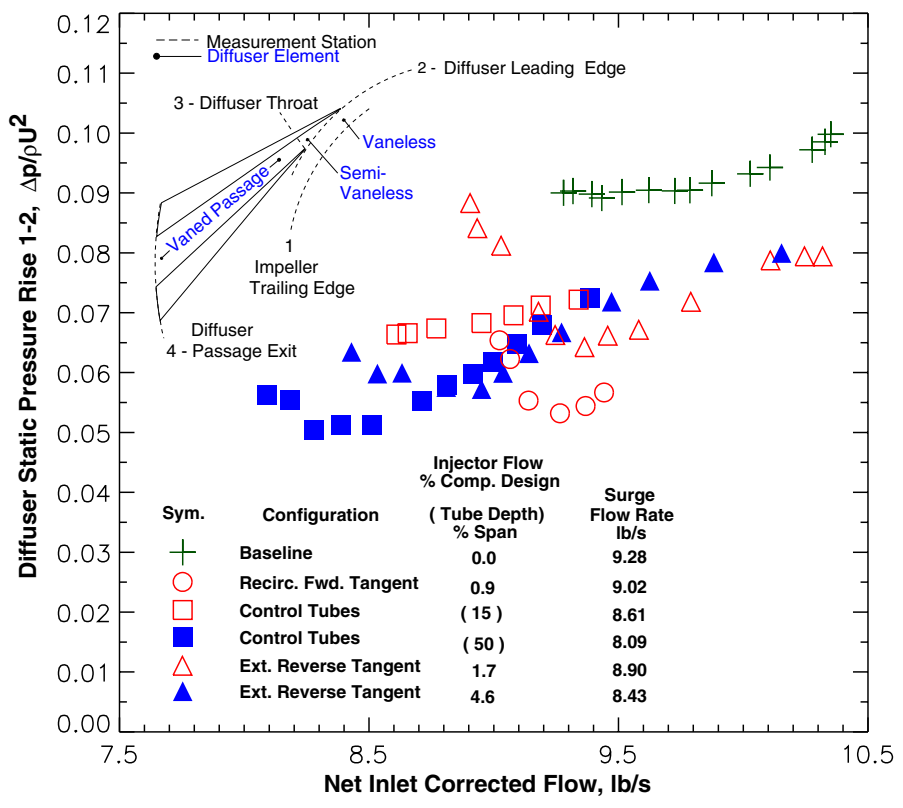

Figure 7: Static Pressure-Rise in the Diffuser Vaneless Space at Design Speed and 2.4 Percent Tip Clearance.

The slope of the vaneless space characteristic is negative near surge on each of the characteristics shown in Figure 7, except one, indicating that the vaneless space was becoming stable near surge. The $15 \%$-control-tube characteristic does not contain the inflection point seen on the other characteristics, suggesting that interaction losses developed more slowly in this configuration.

Semi-vaneless Space. Figure 8 shows the static pressure rise measured across the semi-vaneless space. The characteristics generally maintain a negative slope over most of the flow range. The baseline characteristic exhibits a negative static pressure rise at high through-flow rates that is symptomatic of low swirl angle and negative incidence on the diffuser vanes. Low swirl angle decreases the effective throat area and diffusion across the element is reduced.

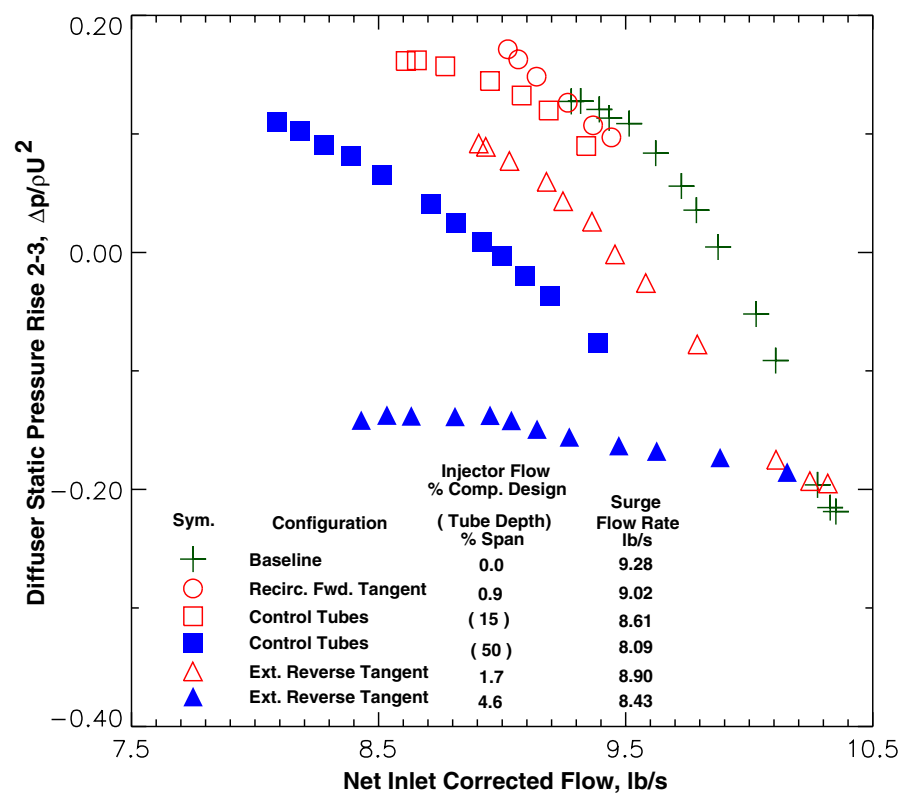

Figure 8: Static Pressure-Rise in the Diffuser Semi-vaneless Region at Design Speed and 2.4 Percent Tip Clearance.

As the compressor is throttled, flow aligns with the throat and diffusion increases. This is demonstrated in Figure 8 by the baseline characteristic as well as the extended range characteristics. The notable difference for the extended range characteristics is that the static pressure rise across this element is lower at a given rate of compressor through-flow. In the case of $4.6 \%$ reverse-tangent injection, the static pressure-rise does not become positive anywhere on the characteristic.

The reasons for this behavior are twofold. First, when tangential velocity near the shroud is reduced and through-flow velocity at a lower span is increased, a lower average swirl angle is maintained to a lower compressor flow rate. Comparing characteristics from the same configuration illustrates this effect. The lower magnitude application in each pair is less effective at maintaining low swirl angle and produces more static pressure rise than its higher magnitude partner. For example, static-pressure rise on 15\%-control-tube characteristic is higher than it is on the $50 \%$-characteristic. The comparison also holds for the 1.7 and 4.6 percent reversetangent injection characteristics.

A total pressure loss is the second reason for the low static pressure observed in the semi-vaneless space. Losses in total pressure across the entire diffuser (shown later) were estimated for each of the range extension techniques tested. The loss across each element was not measured but it is reasonable to assume that a portion of the overall total pressure loss occurs in each element and is reflected in the static pressure rise coefficient across the element.

The 4.6\%-reverse-tangent injection characteristic shows negative static pressure rise along its entire characteristic. The loss coefficient measured across the diffuser was also largest 
for this configuration. The high momentum of the injected stream was directly opposed to the high tangential momentum of the impeller discharge flow. The injection process reduces the tangential velocity of the impeller discharge by mixing and the high losses produced by this process are not surprising.

Vaned Passage. Static pressure rise measurements from the vaned passage are shown in Figure 9. The baseline static pressure rise characteristic exhibits a rapid increase at high compressor through-flow but quickly achieves an unstable positive slope as blockage growth limits diffusion in the passage and decreases static pressure rise at low compressor flow rates.

The extended range configurations, however, generally demonstrate higher static pressure rise than the baseline at low compressor flow rates. The slopes of the $4.6 \%$-reverse-tangent and $15 \%$-control-tube characteristics are negative or turning negative near surge, indicating an improvement in passage stability.

For the extreme case of 4.6\%-reverse-tangent injection, the characteristic in Figure 9 has a negative slope over the entire flow range. This corresponds to a static pressure-rise characteristic in Figure 8 that is below zero over the entire flow range. The conclusion drawn from this comparison is that reducing diffusion in the semi-vaneless region improves passage diffusion. Reduced blockage development in the passage or in the throat can account for this behavior since low momentum fluid resulting from throat blockage will diffuse less effectively.

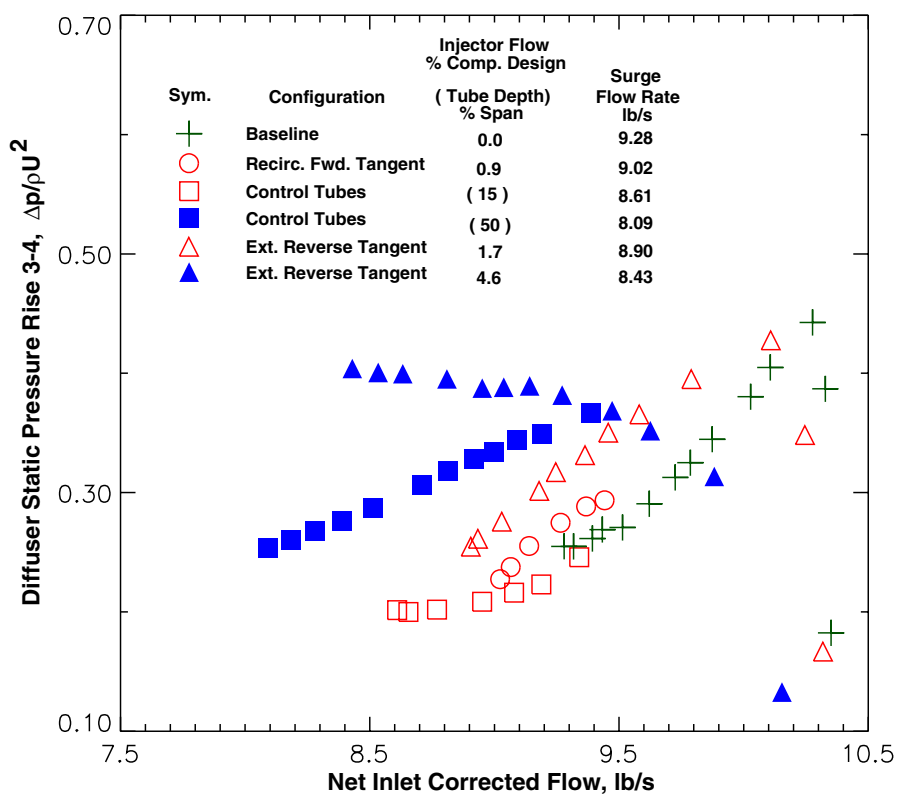

Figure 9: Static Pressure-Rise in the Diffuser Vaned Passage at Design Speed and 2.4 Percent Tip Clearance.

Diffuser Total Pressure Loss. Figure 10 shows the diffuser loss coefficient for each configuration, where:

$$
\omega=\left(\mathrm{P}_{1}-\mathrm{P}_{5}\right) /\left(\mathrm{P}_{1}-\mathrm{p}_{1}\right)
$$

Total pressure at the impeller discharge $\left(\mathrm{P}_{1}\right)$ was estimated using the measured tip speed and stage total-temperature rise to find $V_{\theta}$, where $V_{\theta}$ is the tangential velocity. The impeller tip static pressure $\left(\mathrm{p}_{1}\right)$ and mass flow were used to find the radial component of velocity, $\mathrm{V}_{\mathrm{r}}$. An estimate of blockage at the impeller discharge was needed to estimate $\rho$ and $V_{r}$. A 15 percent reduction of impeller discharge area was used in the estimate of impeller total pressure for all design speed conditions. The assumption of a constant 15 percent area reduction does not provide an exact representation of the actual flow area for each configuration; the goal was simply to provide a comparison of the losses generated by each technique.

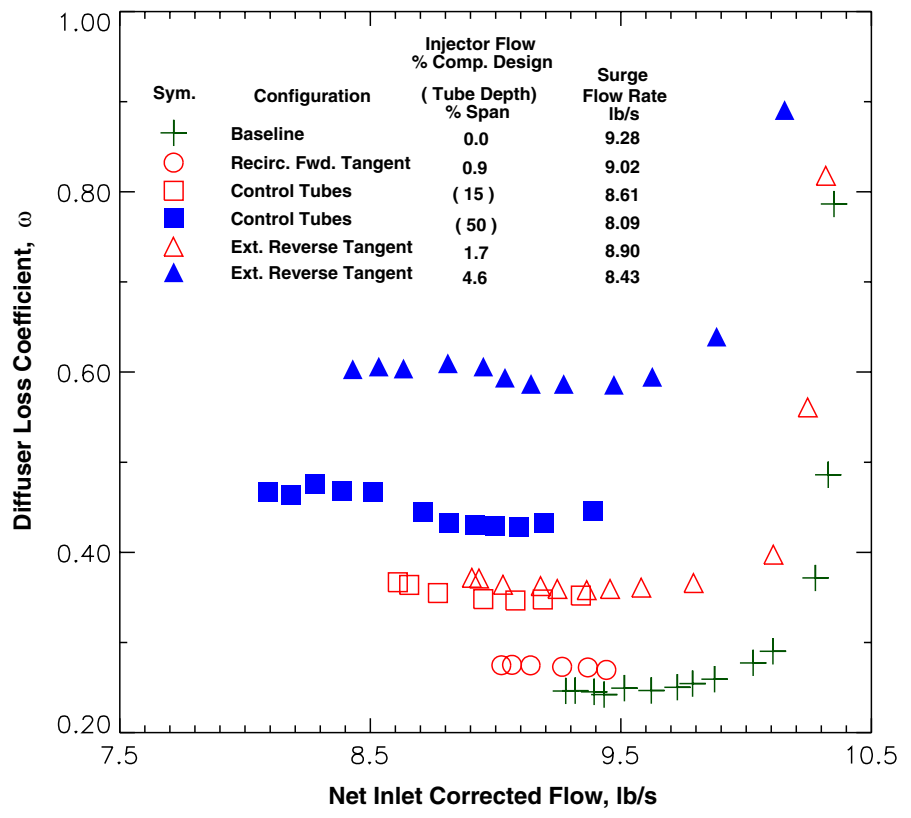
Figure 10: Diffuser Total Pressure Loss Coefficient at
Design Speed and 2.4 Percent Tip Clearance.

The loss coefficient curves for the extended range configurations show that the level of total pressure loss across the diffuser is a function of control action magnitude for similar techniques. Lower loss was produced by $1.7 \%$-reverse-tangent injection than $4.6 \%$-reverse-tangent injection.

Stability may improve, even if surge margin does not, by creating losses in the vaneless space that increase corrected flow into the diffuser. However, a large pressure loss is not a necessary condition for significant flow range improvement. Total pressure loss produced by $4.6 \%$-reverse-tangent injection was much higher than the loss created by the 50\%-controltubes, yet the range improvement provided by the control tubes was greater.

\section{Leading Edge Incidence}

Diffuser vane leading edge incidence was reduced by each of the range improvement techniques that was tested. The change in pressure loading across the leading edge of a diffuser vane is an indicator of changes in leading edge incidence and is 
shown separately for the hub and shroud surfaces in Figures 11 and $\mathbf{1 2}$, respectively.

Loading levels seen in Figure $\mathbf{1 1}$ are generally negative at the hub surface, indicating negative incidence. Since there is not a strong jet-wake profile at the hub, flow discharging from the impeller hub has a lower time-averaged tangential velocity component and a higher through-flow component than flow discharging near the tip. When combined with the viscous drag generated by a transition from the rotating reference frame of the impeller to the stationary frame of the diffuser a significant reduction in swirl angle may result.

Further reductions in loading for a given compressor through-flow rate are demonstrated by the extended range configurations. This is indicative of increased negative hub incidence and shows that the range extension techniques employed on the shroud influenced the diffuser flow field across the entire span. For the extreme case of $4.6 \%$-reversetangent injection, negative incidence at the hub remained fairly constant as the throttle was closed. This is due to a significant reduction in $\mathrm{V}_{\theta}$ coupled with an equally significant increase in $\mathrm{V}_{\mathrm{r}}$ created by the reduction of through-flow area caused by the injected jet.

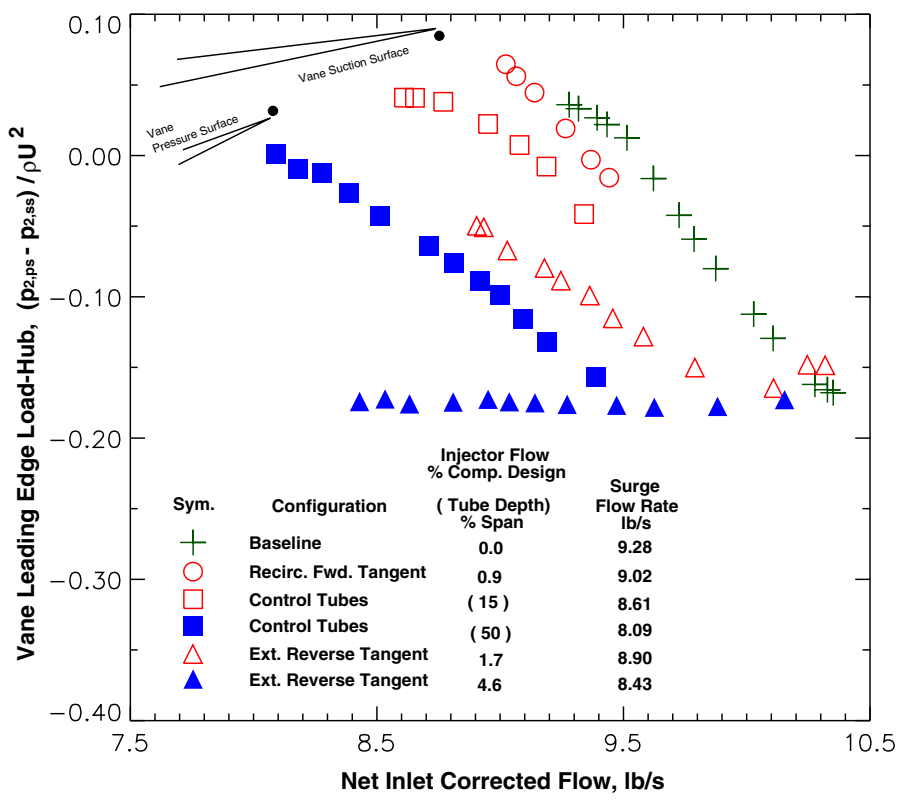

Figure 11: Diffuser Vane Leading Edge Loading on the Hub Surface at Design Speed and 2.4 Percent Tip Clearance.

Leading edge loading at the shroud surface is plotted in Figure 12. Loading levels on the baseline characteristic begin at a higher level and increase faster on the shroud than on the hub. Air discharges from the impeller tip with higher timeaveraged swirl than air at the hub due to the low through-flow velocity fluid that has accumulated near the tip. The result is a more positive incidence on the vane leading edge and higher loading.

A reduction in swirl angle at a given flow rate is evident for each technique from the leading edge loading levels shown in Figure 12. Once again, the loading at a constant compressor flow rate is a function of the control action magnitude for similar methods.

The 15\%-control-tube and forward-tangent methods permitted the leading edge to support a higher loading level at surge than the baseline configuration. This effect was also seen at the hub and suggests that these configurations presented a more uniform flow field to the vane leading edge, permitting it to support a higher load. Reverse-tangent injection, however, reduced the pressure load supported at surge indicating a possible disruption in flow field uniformity.

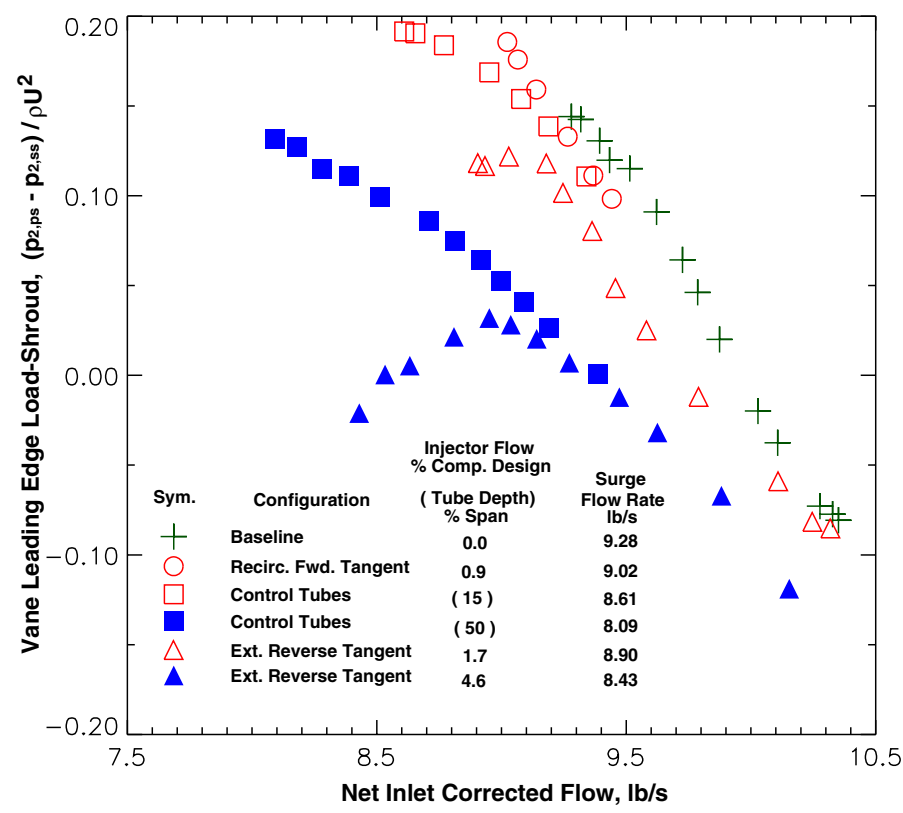

Figure 12: Diffuser Vane Leading Edge Loading on
the Shroud Surface at Design Speed and 2.4 Percent
Tip Clearance.

\section{Backward Rotating Instability Modes}

Spakovszky [8] describes a relationship between compressor geometry and operating condition, repeated below, that can be used to determine the minimum harmonic of backward traveling instability waves that result from dynamic coupling between compressor blade rows.

$$
\frac{\Delta \hat{\mathrm{x}}}{\mathrm{R}}>\frac{\pi}{\mathrm{n}^{2}} \frac{1}{\tan \alpha}
$$

For a centrifugal compressor, $\Delta \hat{\mathrm{x}} / \mathrm{R}$ is a non-dimensional distance between the impeller trailing edge and diffuser leading edge, $\mathrm{n}$ is the minimum harmonic for backward rotating disturbances, and $\alpha$ is the absolute swirl angle entering the diffuser.

When Spakovszky [8] applied the coupling criterion to this compressor it showed that backward traveling waves with harmonics of $n>2.8$ could be expected. His full compressor model predicted backward rotating $3^{\text {rd }}, 4^{\text {th }}, 5^{\text {th }}$ and $6^{\text {th }}$ harmonic disturbances, where disturbances with harmonic numbers above 4 were unstable over the entire characteristic and the 
$4^{\text {th }}$ harmonic became unstable as the compressor was throttled to lower flow rates.

Spakovszky [8] also suggested that disturbances with harmonic numbers above 4 could not exist in this compressor because of a requirement that the disturbance cover at least two impeller blade passages, which left the $4^{\text {th }}$ harmonic disturbance as the instability that contributed most to surge.

The coupling criterion indicates that for a fixed geometry the minimum harmonic of a backward traveling wave increases as swirl angle is reduced. It follows that if the minimum harmonic number for an unstable disturbance is increased to one that can not be supported by compressor geometry, then the contribution of that disturbance to surge is eliminated.

Two of the range improvement techniques tested here significantly reduced the absolute swirl angle in the diffuser vaneless space, which should have increased the minimum harmonic number for backward traveling disturbances. Pressure transducers where not available in sufficient quantity to detect disturbances with high harmonic numbers. However, it still follows that if the minimum harmonic of backward traveling instabilities was increased beyond 4, then backward rotating disturbances could not be maintained in the compressor and the contribution to surge of the original $4^{\text {th }}$ harmonic disturbance would have been eliminated.

\section{Impeller Performance and Stage Efficiency}

Figure 13 shows temperature ratio vs. diffuser throughflow for the baseline configuration and each of the extended range configurations. The total temperature measurements were corrected for the effect of injecting air into the system at a temperature that differed from the local flow. The following correction was applied to the measured total temperature:

$$
\mathrm{T}_{5} \cdot \dot{\mathrm{m}}_{\text {impeller }}=\mathrm{T}_{5 \text {,measured }}\left(\dot{\mathrm{m}}_{\text {impeller }}+\dot{\mathrm{m}}_{\text {injector }}\right)-\mathrm{T}_{\text {injector }} \cdot \dot{\mathrm{m}}_{\text {injector }}
$$

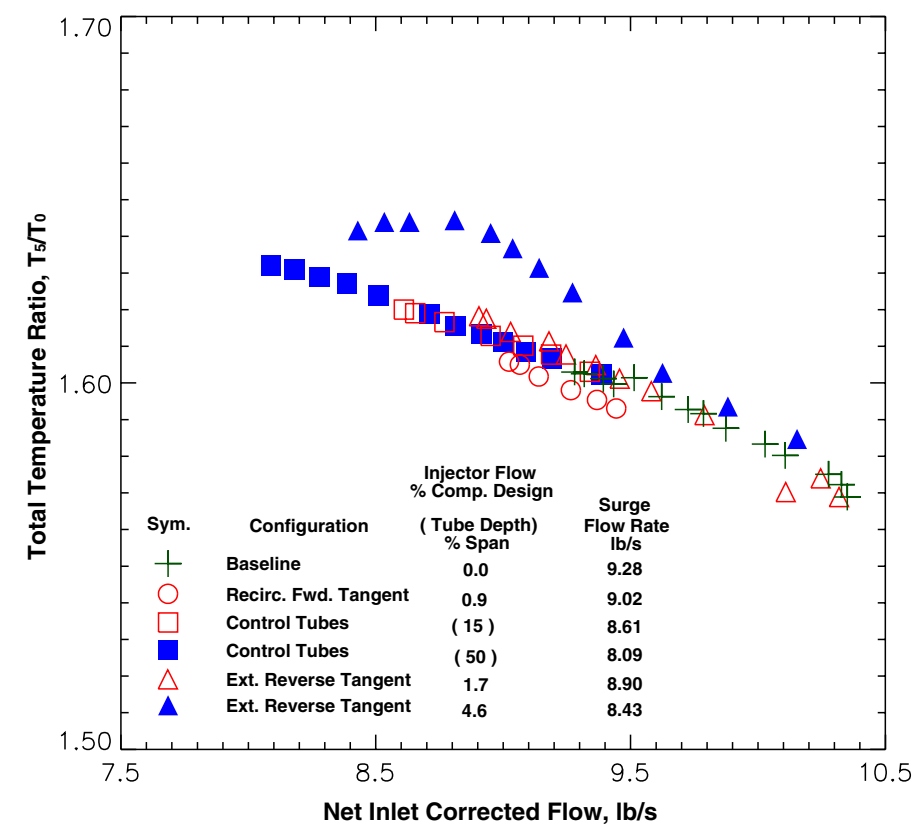

Figure 13: Stage Total Temperature Ratio at Design Speed and 2.4 Percent Tip Clearance.
Impeller work input for each method generally follows the linear trend of the baseline curve and continues to rise as mass flow is reduced below the surge point of the baseline. The linear rise in temperature ratio indicates that $V_{\theta}$ is changing in proportion to $\mathrm{V}_{\mathrm{r}}$ and impeller slip is not heavily influenced by the presence of the injected air streams or control tubes.

A notable exception is the characteristic for reverse tangent injection at the 4.6 percent injector flow rate. This was the highest reverse-tangent flow rate tested and the increasing negative slope on the middle portion of the characteristic implies a net reduction in slip velocity.

Impeller static pressure ratio developed by the baseline compressor and each of the extended range configurations is shown in Figure 14. The slope of the baseline characteristic is negative at the surge point, indicating that the impeller was stable at surge.

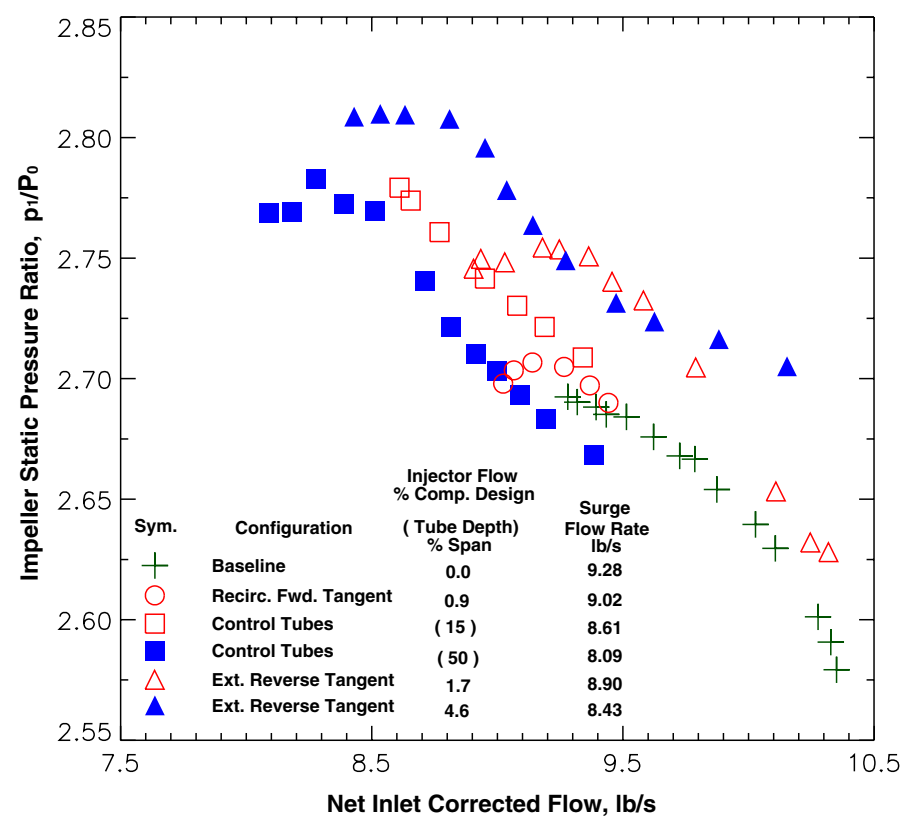

Figure 14: Impeller Static Pressure Ratio for the Baseline and Extended Range Configurations at Design Speed and 2.4 Percent Tip Clearance.

Except for the $15 \%$-control-tube configuration, the altered characteristics acquire a zero or positive slope prior to surge in Figure 14. When this impeller was tested with a vaneless diffuser (Skoch et al. [10]) the stage did not surge until a flow rate of $7.2 \mathrm{lb}_{\mathrm{m}} / \mathrm{s}(3.3 \mathrm{~kg} / \mathrm{s})$ was reached. The changing slopes seen here at flow rates above $7.2 \mathrm{lb}_{\mathrm{m}} / \mathrm{s}$ suggest that each technique eventually began to destabilize the impeller. Forward-tangent injection destabilized the impeller much sooner in terms of compressor flow rate.

Increased impeller work input in the extended flow region of the characteristics produced higher total pressure at the impeller exit that mitigated somewhat, the effect of diffuser loss on stage pressure ratio. However, with increased impeller work input and a lower stage total pressure ratio, the stage efficiency is adversely impacted as seen in Figure 15. 


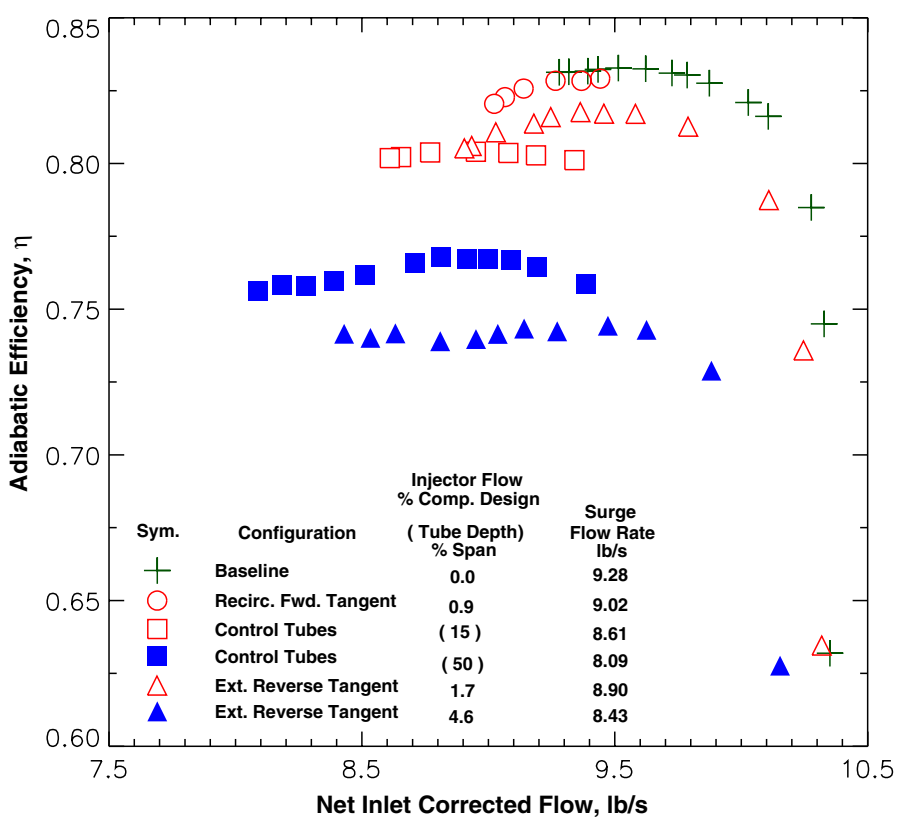

Figure 15: Stage Adiabatic Efficiency at Design Speed and 2.4 Percent Tip Clearance.

\section{PRACTICAL IMPLICATIONS}

Pressure loss incurred across the diffuser precludes the continuous use of any of the techniques described herein. However, it would make sense to employ these techniques if they can be used intermittently, turned on when the onset of compression system instability is detected and then turned off when stable operation returns. An intermittent operating strategy would make it possible to take advantage of improved stability provided by operating on the altered characteristics without enduring the penalty of a pressure loss during stable operation.

The feasibility of preventing surge by activating one of the techniques described above is demonstrated in Figure 16 where reverse-tangent injection was used to bring the compressor out of surge. The figure shows the change in absolute compressor through-flow with time, at design speed, as the throttle is closed to initiate surge and then as the compressor is stabilized using reverse-tangent injection.

Injection was initiated using a hand-operated valve when audible surge was detected. Only two injectors, 4 and 5 in Figure 2, were used for this test. The total injected flow rate went from 0 to a value of 2.9 percent of design flow when the valve was first opened. As only two nozzles were in use, the flow through each nozzle was roughly equal to 1.5 percent of compressor design flow and both nozzles were choked.

Throttle closing continued, with injection stabilizing the compressor, until the compressor surged a second time. At the second surge point, both injectors were choked and additional supply pressure to raise injector mass flow was not available so a second recovery could not be accomplished. The throttle was then opened to bring the compressor out of surge.

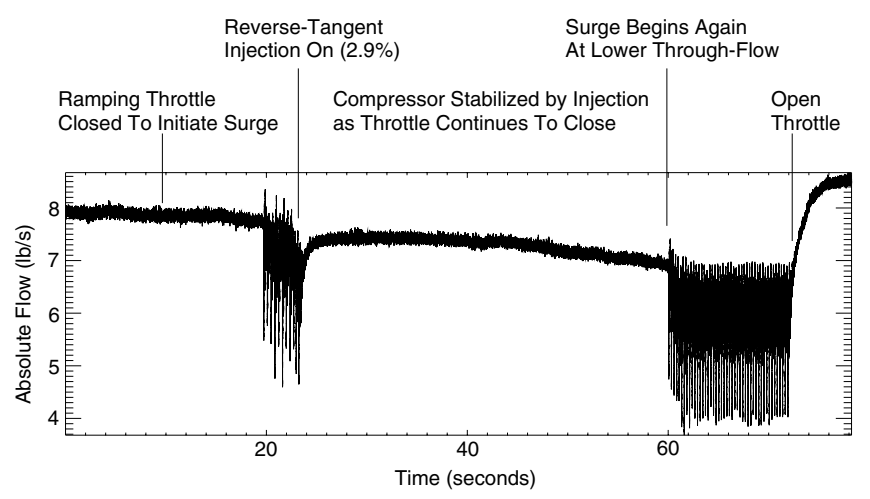

Figure 16: Recovery from Surge Using Reverse-Tangent Injectors 4 and $\mathbf{5}$ at 100 Percent of Design Speed and 2.4 Percent Tip Clearance.

If recovery from a fully developed surge condition can be accomplished then control actions taken at the first sign of instability should also stabilize the compressor. The test was not repeated using the control tubes or forward-tangent injection, since on-off control could not be done remotely. However, it seems reasonable that retractable control tubes and controllable recirculation valves could also be used to the limits of their effectiveness.

\section{SUMMARY}

Three techniques to extend the stable flow range of a $4: 1$ pressure ratio centrifugal compressor have been demonstrated.

Table 1 summarizes the results obtained from each technique. Surge margin, computed along a line of constant compressor-exit corrected flow, is shown for each technique in Column A. The improvement over the baseline surge margin $\left(\mathrm{SM}-\mathrm{SM}_{\text {Baseline }}\right)$ is shown in Column $\mathrm{B}$. The change in stage pressure ratio at surge, $\left(\mathrm{PR}-\mathrm{PR}_{\text {Baseline }}\right) / \mathrm{PR}_{\text {Baseline }} \times 100 \%$, is given in Column $\mathrm{C}$.

Table 1: Comparison of Changes in Surge Margin and Pressure Ratio

\begin{tabular}{|l|c|c|c|}
\hline \multicolumn{1}{|c|}{ Configuration } & $\begin{array}{c}\text { A } \\
\text { Surge } \\
\text { Margin } \\
(\%)\end{array}$ & $\begin{array}{c}\text { B } \\
\Delta \text { Surge } \\
\text { Margin } \\
(\%)\end{array}$ & $\begin{array}{c}\text { C } \\
\Delta \text { PR } \\
\text { At Surge } \\
(\%)\end{array}$ \\
\hline Baseline & 11.7 & - & - \\
\hline $0.9 \%$-Forward-Tangent & 13.4 & 1.7 & -1.0 \\
\hline 1.7\%-Reverse-Tangent & 12.7 & 1.0 & -2.6 \\
\hline 4.6\%-Reverse-Tangent & 9.7 & -2.0 & -11.0 \\
\hline 15\%-Control-Tubes & 16.1 & 4.4 & -1.4 \\
\hline $50 \%$-Control-Tubes & 18.2 & 6.5 & -5.5 \\
\hline
\end{tabular}

Forward-tangent injection using recirculated air caused very little pressure loss in the diffuser so an improvement in surge margin was demonstrated even though the stable flow range improvement was relatively small. Reverse-tangent 
injection produced the highest losses in stage pressure ratio for the increase in stable flow range that was achieved. It provided only a small improvement in surge margin and only at a low injected flow rate. Control tubes produced significant improvement in stable flow range with only moderate pressure loss in the diffuser, hence, the greatest surge margin improvement.

The range improvement techniques acted on flow in the diffuser vaneless space and caused a reduction in average swirl angle across the span. Lower swirl angle produced the following results:

1) Diffusion between the impeller exit and diffuser throat was reduced.

2) Incidence on the diffuser vane leading edge was reduced.

3) Backward rotating instability modes may have been eliminated.

Each technique produced some loss of total pressure in the diffuser. Pressure losses created in the diffuser vaneless space helped stabilize the compressor by throttling the diffuser but resulted in poor compressor performance and surge margin. Excessive pressure loss in the diffuser was not a necessary condition for stability improvement, however. Reducing the average swirl angle across the span of the vaneless space as the compressor approached surge was the important control action. If swirl angle reductions could be achieved with minimal pressure loss when approaching surge, then both performance and stability would be maintained.

The loss in total pressure across the diffuser precludes continuous operation using the techniques demonstrated here. However, an operating strategy that activates a particular technique when compression system instability is detected would be a practical alternative in order to take advantage of the significant stability improvement that is available.

Recovery from fully developed compressor surge using this strategy was demonstrated using reverse-tangent injection. However, based on measured surge margin improvement, retractable control tubes would be the best of the three methods tested here for an intermittent operating strategy.

\section{NOMENCLATURE}

$\begin{array}{ll}\mathrm{P} & \text { total pressure } \\ \mathrm{P} & \text { static pressure } \\ \mathrm{T} & \text { total temperature } \\ \mathrm{T}_{5} & \begin{array}{l}\text { total temperature at exit rake plane after } \\ \text { correcting for injection }\end{array} \\ \mathrm{T}_{5, \text { measured }} & \text { measured total temperature at exit rake plane } \\ \mathrm{T}_{\text {injector }} & \text { total temperature of injector flow } \\ \dot{\mathrm{m}}_{\text {ref }} & \text { impeller net inlet corrected mass flow at constant } \\ & \text { exit corrected flow reference point } \\ \dot{\mathrm{m}}_{\text {surge }} & \text { impeller net inlet corrected mass flow at surge } \\ \dot{\mathrm{m}}_{\text {impeller }} & \text { impeller absolute mass flow }\end{array}$

\begin{tabular}{|c|c|}
\hline$\dot{\mathrm{m}}_{\text {injector }}$ & injector absolute mass flow \\
\hline$\pi_{\text {ref }}$ & $\begin{array}{l}\text { stage total pressure ratio at constant exit corrected } \\
\text { flow reference point }\end{array}$ \\
\hline$\pi_{\text {surge }}$ & stage total pressure ratio at surge \\
\hline \multirow[t]{2}{*}{ SM } & surge margin, $\left(1-\underline{\pi_{\mathrm{ref}}} \cdot \underline{\text { msurge }}\right) \times 100 \%$ \\
\hline & $\boldsymbol{\pi}_{\text {surge }} \dot{\text { mref }}$ \\
\hline $\mathrm{SM}_{\text {Baseline }}$ & surge margin on baseline characteristic \\
\hline$\rho U^{2}$ & impeller dynamic head \\
\hline$\Delta \mathrm{H}_{\text {isen }}$ & isentropic enthalpy rise \\
\hline$\Delta \mathrm{H}_{\mathrm{act}}$ & actual enthalpy rise \\
\hline$\eta$ & adiabatic efficiency, $\Delta \mathrm{H}_{\text {isen }} / \Delta \mathrm{H}_{\text {act }}$ \\
\hline \multicolumn{2}{|c|}{ Measurement Station Subscripts } \\
\hline 0 & upstream plenum \\
\hline 1 & impeller trailing edge \\
\hline 2 & diffuser vane leading edge \\
\hline 3 & diffuser throat \\
\hline 4 & diffuser exit \\
\hline 5 & rake plane in diffuser exit passage \\
\hline
\end{tabular}

\section{REFERENCES}

1. Rodgers, C., 1982, "The Performance of Centrifugal Compressor Channel Diffusers," ASME Paper No. 82-GT-10.

2. Rundstadler, P.W., Jr. and Dean, R.C., Jr., 1969, "Straight Channel Diffuser Performance at High Inlet Mach Numbers," ASME Journal on Basic Engineering, Vol. 91, No. 3, pp. 397-422.

3. Jansen, W., Carter, A.F., and Swarden, M.C., 1980, "Improvements in Surge Margin for Centrifugal Compressors," Centrifugal Compressors, Flow Phenomena and Performance, AGARD-CP-282, No. 19.

4. Raw, J.A., 1986, "Surge Margin Enhancement by a Porous Throat Diffuser," Canadian Aeronautics and Space Journal, Vol. 32, No. 1, pp. 54-60.

5. Nelson, E.B., Paduano, J.D., and Epstein, A.H., 2000, "Active Stabilization of Surge in an Axial Centrifugal Turboshaft Engine," ASME J. of Turbomachinery, Vol. 122, pp. 485-493.

6. Stein, A., Saeid, N., and Sankar, L.N., 2000, "Numerical Analysis of Stall and Surge in a High-Speed Centrifugal Compressor," $38^{\text {th }}$ Aerospace Sciences Meeting \& Exhibit, Reno, NV, AIAA paper No. 2000-0226.

7. Oakes, W.C., Lawless, P.B., and Fleeter, S., 1999, "Instability Pathology of a High Speed Centrifugal Compressor," ASME Turbo Expo, Indianapolis, Indiana, ASME paper No. 99-GT-415.

8. Spakovszky, Z.S., 2002, "Backward Traveling Rotating Stall Waves in Centrifugal Compressors," ASME Turbo Expo, Amsterdam, The Netherlands, ASME paper No. GT-2002-2039.

9. McKain, T.F., and Holbrook, G.J., 1982, "Coordinates for a High Performance 4:1 Pressure Ratio Centrifugal Compressor,” NASA Contractor Report No. 204134.

10. Skoch, G.J., Prahst, P.S., Wernet, M.P., Wood, J.R., and Strazisar, A.J., 1997, "Laser Anemometer Measurements of the Flow Field in a 4:1 Pressure Ratio Centrifugal Impeller," ASME Turbo Expo, Orlando, Florida, ASME paper No. 97-GT-342.

11. Wernet, M.P., Bright, M.M., and Skoch, G.J., 2001, "An Investigation of Surge in a High-Speed Centrifugal Compressor Using Digital PIV," Transactions of the ASME, Vol. 123, pp. $418-428$. 

Public reporting burden for this collection of information is estimated to average 1 hour per response, including the time for reviewing instructions, searching existing data sources, gathering and maintaining the data needed, and completing and reviewing the collection of information. Send comments regarding this burden estimate or any other aspect of this collection of information, including suggestions for reducing this burden, to Washington Headquarters Services, Directorate for Information Operations and Reports, 1215 Jefferson Davis Highway, Suite 1204, Arlington, VA 22202-4302, and to the Office of Management and Budget, Paperwork Reduction Project (0704-0188), Washington, DC 20503.

\begin{tabular}{|l|l|l}
\hline 1. AGENCY USE ONLY (Leave blank) & $\begin{array}{c}\text { 2. REPORT DATE } \\
\text { December } 2003\end{array}$ & $\begin{array}{r}\text { 3. REPORT TYPE AND DATES COVERED } \\
\text { Technical Memorandum }\end{array}$ \\
\hline
\end{tabular}

4. TITLE AND SUBTITLE 5. FUNDING NUMBERS

Experimental Investigation of Centrifugal Compressor Stabilization Techniques

6. AUTHOR(S)

WBS-22-708-28-03

1L161102AF20

Gary J. Skoch

7. PERFORMING ORGANIZATION NAME(S) AND ADDRESS(ES)

8. PERFORMING ORGANIZATION REPORT NUMBER

National Aeronautics and Space Administration

John H. Glenn Research Center at Lewis Field

Cleveland, Ohio 44135-3191

E-14156

\section{SPONSORING/MONITORING AGENCY NAME(S) AND ADDRESS(ES)}

National Aeronautics and Space Administration

Washington, DC 20546-0001

and

U.S. Army Research Laboratory

Adelphi, Maryland 20783-1145
10. SPONSORING/MONITORING AGENCY REPORT NUMBER

NASA TM-2003-212599

ARL-TR-2921

GT-2003-38524

\section{SUPPLEMENTARY NOTES}

Prepared for the Turbo Expo 2003 cosponsored by the American Society of Mechanical Engineers and the International Gas Turbine Institute, Atlanta, Georgia, June 16-19, 2003. Responsible person, Gary J. Skoch, organization code 5810, 216-433-3396.

Unclassified - Unlimited

Subject Category: 07

Distribution: Nonstandard

Available electronically at http://gltrs.grc.nasa.gov

This publication is available from the NASA Center for AeroSpace Information, 301-621-0390.

\section{ABSTRACT (Maximum 200 words)}

Results from a series of experiments to investigate techniques for extending the stable flow range of a centrifugal compressor are reported. The research was conducted in a high-speed centrifugal compressor at the NASA Glenn Research Center. The stabilizing effect of steadily flowing air-streams injected into the vaneless region of a vane-island diffuser through the shroud surface is described. Parametric variations of injection angle, injection flow rate, number of injectors, injector spacing, and injection versus bleed were investigated for a range of impeller speeds and tip clearances. Both the compressor discharge and an external source were used for the injection air supply. The stabilizing effect of flow obstructions created by tubes that were inserted into the diffuser vaneless space through the shroud was also investigated. Tube immersion into the vaneless space was varied in the flow obstruction experiments. Results from testing done at impeller design speed and tip clearance are presented. Surge margin improved by 1.7 points using injection air that was supplied from within the compressor. Externally supplied injection air was used to return the compressor to stable operation after being throttled into surge. The tubes, which were capped to prevent mass flux, provided 9.3 points of additional surge margin over the baseline surge margin of 11.7 points.

\begin{tabular}{|c|c|c|}
\hline \multicolumn{3}{|c|}{$\begin{array}{l}\text { 14. SUBJECT TERMS } \\
\text { Centrifugal; Compressor; Stall; Surge }\end{array}$} \\
\hline $\begin{array}{l}\text { 17. SECURITY CLASSIFICATION } \\
\text { OF REPORT } \\
\text { Unclassified }\end{array}$ & $\begin{array}{l}\text { 18. SECURITY CLASSIFICATION } \\
\text { OF THIS PAGE } \\
\text { Unclassified }\end{array}$ & $\begin{array}{l}\text { 19. SECURITY CLASSIFICATION } \\
\text { OF ABSTRACT } \\
\text { Unclassified }\end{array}$ \\
\hline
\end{tabular}

15. NUMBER OF PAGES

18

16. PRICE CODE 